\section{THU0611 LONG-TERM FOLLOW-UP OF 269 CHILDREN BORN TO MOTHERS WITH SYSTEMIC AUTOIMMUNE DISEASES: A NATIONAL SURVEY FROM 24 RHEUMATOLOGY CENTERS}

C. Nalli ${ }^{1}$, L. Andreoli ${ }^{1}$, C. Carini ${ }^{1}$, M. Rodrigues ${ }^{2}$, F. Dall'Ara ${ }^{1}$, M.G. Lazzaroni ${ }^{1}$, E. Bartoloni-Bocci ${ }^{3}$, C.B. Chighizola ${ }^{4}$, C. Campochiaro ${ }^{4}$, P. Conigliaro ${ }^{5}$

A. Corrado ${ }^{6}$, S. D'Angelo ${ }^{7}$, M. Favaro ${ }^{8}$, E. Generali ${ }^{4}$, M. Gerosa ${ }^{4}$, M. Larosa ${ }^{8}$, M. Meroni ${ }^{9}$, M. Padovan ${ }^{10}$, G. Pazzola ${ }^{11}$, S. Peccatori ${ }^{12}$, I. Prevete ${ }^{5}$,

V. Ramoni ${ }^{13}$, G. Sebastiani ${ }^{5}$, V. Signorini ${ }^{14}$, C. Tani ${ }^{14}$, M. Trevisani ${ }^{15}$

M. Vadacca ${ }^{5}$, E. Vivaldelli ${ }^{16}$, E. Visalli ${ }^{17}$, L. Zuliani ${ }^{18}$, A. Afeltra ${ }^{5}$, E. Baldissera ${ }^{4}$,

A. Brucato ${ }^{19}$, F.P. Cantatore ${ }^{6}$, R. Caporali ${ }^{13}$, M. Cutolo $^{9}$, A. Doria ${ }^{8}$, R. Foti ${ }^{17}$,

A. Gabrielli ${ }^{18}$, R. Gerli ${ }^{3}$, M. Govoni ${ }^{10}$, A. Maier ${ }^{16}$, N. Malavolta ${ }^{15}$, P.L. Meroni ${ }^{4}$,

G. Minisola ${ }^{5}$, C.M. Montecucco ${ }^{13}$, M. Mosca $^{14}$, I. Olivieri ${ }^{7}$, G. Paolazzi ${ }^{12}$,

R. Perricone ${ }^{5}$, N. Romeo ${ }^{20}$, A. Ruffatti $^{8}$, M.G. Sabbadini ${ }^{4}$, C. Salvarani ${ }^{11}$,

C. Selmi ${ }^{4}$, L. Sinigaglia ${ }^{4}$, A. Tincani ${ }^{1}{ }^{4}{ }^{1}$, Brescia, Italy; ${ }^{2}$-, Coimbra, Portugal, ${ }^{3}{ }^{-}$, Perugia; ${ }^{4}-$, Milano; ${ }^{5}-$, Roma; ${ }^{6}-$, Foggia; ${ }^{7}{ }^{-}$, Matera-Potenza; ${ }^{8}-$, Padova; ${ }^{9}$,

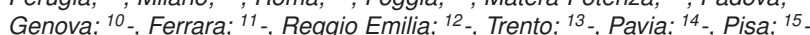
Bologna; ${ }^{16}{ }_{-}$, Bolzano; ${ }^{17}$-, Catania; ${ }^{18_{-}, \text {Ancona; }}{ }^{19}{ }_{-}$, Bergamo; ${ }^{20}$-, Cuneo, Italy

Background: Rheumatic diseases (RD) affect women during reproductive age. Children's outcome is a major topic for counselling on family planning, but no large studies are available.

Objectives: We aimed at assessing the long-term health conditions of children born to mothers with RD through a self-reported questionnaire.

Methods: 24 Rheumatology Centers distributed the questionnaire (65 multiple choice and 12 open-answer questions) to consecutive women with RD attending their outpatient clinic during September 2015. Data were compared according to maternal diagnosis $(\mathrm{MD})$-chronic arthritis $(\mathrm{CA})$ or connective tissue disease (CTD)- and to the timing of pregnancy (before or after MD of RD).

Results: The survey yielded data about 269 children born to 184 mothers (63 CA, 121 CTD). According to MD, children had a mean age of 17.1 ( $\pm 9.6 \mathrm{SD}$ ) and $14.4( \pm 9.0 \mathrm{SD})$ years at the time of interview, and male children were $52 / 93(56 \%)$ and $91 / 176(52 \%)$, respectively. Twenty-nine children in the CA group (31.2\%) and 64 in the CTDs group (36.4\%) were born after MD of RD. Pre-term delivery (before 37 weeks) was observed in 48 cases $(17.8 \%)$, mostly children born to mothers with CTD $(37 / 48,77 \%)$.

Regarding school performance, 12 children (4.5\%) repeated one year of school, in 7 cases for indolence, in 3 for learning disabilities (LD)/health problems (HP), in 2 for family problems. Eleven of these children were born before MD. Overall, 9 children $(3.3 \%)$ were diagnosed with a LD and 53 children were affected by HP requiring either hospitalization or evaluation by a Specialist (Table). Three children (1\%) were affected by autoimmune disease.

\begin{tabular}{|c|c|c|}
\hline $\begin{array}{l}269 \text { children born to } \\
\text { mothers with RDs }\end{array}$ & $\begin{array}{l}\text { Children born to women } \\
\text { with CA }(n=93)\end{array}$ & $\begin{array}{l}\text { Children born to women } \\
\text { with CTDs }(n=176)\end{array}$ \\
\hline \multicolumn{3}{|c|}{ LEARNING DISABILITIES AND NEURODEVELOPMENTAL DISORDERS $n=9 / 269(3.3 \%)$} \\
\hline BEFORE maternal diagnosis & $\begin{array}{c}1 / 64(1.6 \%) \\
1 \text { "slow learner" (1 SGA female) }\end{array}$ & $\begin{array}{c}4 / 112(3.6 \%) \\
2 \text { LD; } 1 \text { ADHD; } 1 \text { Autism Spectrum Disorder }\end{array}$ \\
\hline $\begin{array}{l}\text { AFTER maternal diagnosis } \\
\text { In utero exposure: } \\
\text { - to drugs } \\
\text { - to maternal autoantibodies }\end{array}$ & $0 / 29(0 \%)$ & $\begin{array}{c}4 / 64 \text { (6.3\%) } \\
3 \text { LD; } 1 \text { ADHD } \\
n=3 \text { (3 lawk dose prednisone; } 1 \text { azathisocioe) } \\
n=4 \text { (3 ANA, } 2 \text { anti-\$sDNA, } 2 \text { anti-Ro/SSA, } \\
2 \text { aCL LGG) }\end{array}$ \\
\hline \multicolumn{3}{|c|}{ HEALTH PROBLEMS (ACUTE AND CHRONIC DISEASES) $n=53 / 269(19.7 \%)$} \\
\hline BEFORE maternal diagnosis & 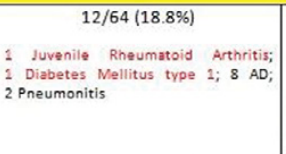 & $\begin{array}{l}23 / 112(20.5 \%) \\
1 \text { Chronic Autoimmune Thyroiditis; } 1 \text { Early } \\
\text { infantile epileptic encephalopathy; } 1 \\
\text { perinatal death (respiratory distresst; } 3 \text { CD; } 5 \\
\text { AD; } 4 \text { acute disease } * 4 \text { chronic disease"; } \\
4 \text { surgery }\end{array}$ \\
\hline AFTER maternal diagnosis & $\begin{array}{c}/ 29(10.3 \%) \\
1 \text { Trisomy 21; } 1 \text { Enterovirus meningitis; } \\
1 \text { CD }+A D\end{array}$ & $\begin{array}{l}15 / 64(23.4 \%) \\
1 \text { FUO; } 3 \text { CD; } 5 . A D ; 1 \text { acute disease"; } \\
2 \text { chronic disease"; } 3 \text { surgery }\end{array}$ \\
\hline
\end{tabular}

Conclusions: The long-term follow-up of children born to women with RD is reassuring of an outcome similar to that of the general pediatric population (GPP). Autoimmune diseases are not frequent. Problems seem to cluster in children born to CTD, especially after MD, with a higher frequency of LD $(6.3 \%$ vs $2.5-3.5 \%$ of GPP), but no particular pattern of exposure to maternal autoantibodies nor drugs was observed.

Acknowledgements: Statistical analysis supported by an unrestricted grant by UCB Pharma

Thanks to Patients Associations and Participants to the survey

Disclosure of Interest: None declared

DOI: 10.1136/annrheumdis-2017-eular.1844

\section{THU0612 PROVIDING HEALTHCARE FOR THE POOREST IN EAST INDIA - A REPORT FROM A CHARITY INITIATIVE, SHAKUNTALA HOSPITAL}

C.H. Brahe, U. Rydholm, M. Pikwer, K. Schreiber, C. Ståhl-Hallengren, B. Bylander, R. Dash. The Indo-Swedish Rheumatology Foundation (ISRF), Malmø, Sweden

Background: The region of Odisha in India has a population of over 40 million people and $45 \%$ are living in poverty. Approximately one percent of the population is affected by inflammatory rheumatoid diseases. In order to provide early diagnosis and adequate treatment initiation to prevent long term disability, patients require easily accessible basic health care and rheumatologists.

Accessible and affordable health care for patients with inflammatory diseases may not only improve disease diagnosis and management, but also improve their quality of life significantly

Objectives: The aim of our abstract is:

1) To raise awareness of the need of support for common rheumatoid diseases in the developing world

2) To present Shakuntala Hospital as an example of a successful charity initiative Methods: The Indo-Swedish Rheumatology Foundation (ISRF) is an association of physicians whose main aim is to raise awareness, fundraise and to provide health care for patients suffering from inflammatory arthropathies. In order to bridge the gap between our advanced level of knowledge and treatment options in the western world and patients suffering from rheumatologic diseases in the Indian state Odisha we have established this unique association. ISRF, including Shakuntala Hospital, was founded in 2013 and has so far not only provided health care through diagnostic and treatment support, but also ensured patient education and physiotherapy. Health camps are organized in the peripheral communities in order to screen, diagnose and initiate first line treatment and refer these patients for follow-up care to Shakuntala Hospital for further treatments with disease modifying antirheumatic drugs (DMARD), disease monitoring and physiotherapy. Shakuntala Hospital is an example of a non-profit hospital with the aim to provide health care amongst the poorest areas in India.

Results: We have so far registered over 2,000 patients under our care, which includes patients registered in Shakuntala Hospital and in our peripheral care health camps. So far we have established outpatient care for patients with inflammatory arthritis in the districts of Balasore, Maurbhanja, Bhddark, Keonjhar, Jajpur districts of Odisa and Mednapur district of West Bengal and raised more than 32.000 Euro by ISRF from fundraising initiatives.

Inspired by a Swedish model our osteoarthritis (OA) school was founded in October 2016 providing 6 week training courses with the main focusing on patients with knee OA.

Furthermore, ISRF has increased awareness of skeletal fluorosis and provide a comprehensive focus with cleaning of drink water in co-operation with the Royal Technical High School in Stockholm.

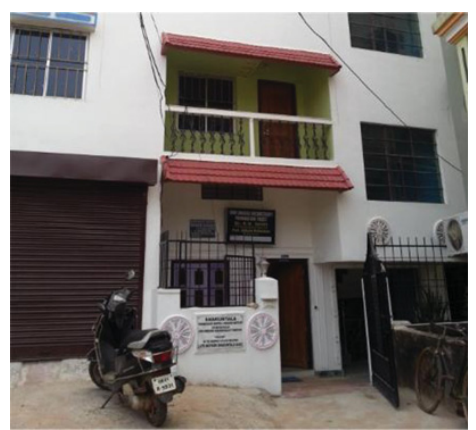

Conclusions: Shakuntala Hospital is an example of a successful charity initiative in order to provide healthcare for the poorest patients in East India. Awareness needs to be risen in order to further foster future support for Shakuntala Hospital. References:

[1] http://www.shakuntalahospital.com/.

Disclosure of Interest: None declared

DOI: 10.1136/annrheumdis-2017-eular.4424

\section{THU0613 EXPLORING THE IMPACT OF HEALTH STATUS AND WELL-BEING OF PEOPLE WITH INFLAMMATORY ARTHRITIS ON PRESENTEEISM IN THE WORKPLACE: A QUALITATIVE STUDY}

C.J. Jones ${ }^{1}$, K. Payne ${ }^{1}$, B. Gannon ${ }^{2}$, S. Verstappen ${ }^{3} .{ }^{1}$ Manchester Centre for Health Economics, The University of Manchester, Manchester, United Kingdom; ${ }^{2}$ Mater Research Institute Chair in Health Economics, Centre for Business and Economics of Health, Brisbane, Australia; ${ }^{3}$ Arthritis Research UK Centre for Epidemiology, Centre for Musculoskeletal Research, Manchester, United Kingdom

Background: Presenteeism can be defined as the reduction in work performance due to ill-health at the workplace. Musculoskeletal conditions, including 